\title{
Phase variation in Flavobacterium psychrophilum: characterization of two distinct colony phenotypes
}

\author{
Eva Högfors-Rönnholm*, Tom Wiklund \\ Laboratory of Aquatic Pathobiology, Department of Biology, Åbo Akademi University, BioCity, Tykistökatu 6, \\ 20520 Turku, Finland
}

\begin{abstract}
Four 'smooth' and 4 'rough' colony phenotypes of the Gram-negative fish pathogen Flavobacterium psychrophilum isolated from rainbow trout Oncorhynchus mykiss were characterized using biochemical, physiological, molecular and virulence tests to better understand the pathogenesis of the bacterium. Biochemically, the 2 cell types did not react significantly differently. Physiologically, the 2 phenotypes had distinct characteristics, and, when grown in broth, the smooth cells were found to be autoagglutinating and able to switch into the non-agglutinating rough phenotype. The rough cells did not switch into the smooth phenotype under any growth conditions tested, indicating that the phase variation from the smooth to rough phenotype is irreversible or that the conditions for the reversible switch are still to be found. Smooth cells were hydrophobic and more adhesive compared to the hydrophilic rough cells, suggesting that the phase variation most probably involves one or several surface structures other than outer membrane proteins and lipopolysaccharides that were found to be similar in both types. Analysis of extracellular products produced by the 2 cell types indicated furthermore that a difference in enzymatic activities could exist. Both cell types were virulent for rainbow trout in an intramuscular challenge; thus, the distinct physiological characteristics of the phenotypes do not seem to be directly associated with virulence, when the body surface of the fish is disregarded. The results suggest that phase variation occurs in F. psychrophilum, but that the importance of the 2 phenotypes for the pathogenesis of the bacterium has still to be investigated.
\end{abstract}

KEY WORDS: Flavobacterium psychrophilum • Colony phenotype $\cdot$ Phase variation $\cdot$ Phenotypic conversion · Surface structures

\section{INTRODUCTION}

To be able to survive and compete for nutrients in a sometimes quite extreme environment, bacteria have adapted to their surroundings by being able to change both morphologically and physiologically (Roszak \& Colwell 1987). A change in phenotype, in the laboratory often seen as a change in colony morphology, is often referred to as phase variation in bacteria and is a result of a change in expression of one or more genes that often leads to altered surface structures on the bacterial cells. The genes, and the subsequent structures the genes are encoding, which are affected by phase variation can vary between different bacterial species (van der Woude \& Bäumler 2004). For pathogenic bacteria, a switch between 2 or more phenotypes can enable the cells to evade the immune system of the host or to colonize different sites in the host. In the environment, phase variation can, furthermore, be a way for the bacteria to switch between a dispersing and a biofilm-forming phenotype (van der Woude 2006).

For Flavobacterium psychrophilum, a Gram-negative pathogenic bacterium that causes bacterial cold water disease in freshwater salmonids (Nematollahi et al. 2003), it is known that 2 different colony phenotypes can be isolated from diseased fish. These colony types have been described as yellow with regular edges and yellow with spreading margins (Pacha 1968, Holt 1987, Bernardet \& Kerouault 1989). In a stereomicroscope the appearance of the 2 colony types is smooth and rough, respectively. To our knowledge, 
there are no reports of a detailed characterization of these 2 colony types, nor have any studies associated the different phenotypes with phase variation in $F$. psychrophilum.

A variety of biochemical, physiological, serological, molecular, genetic and antigenic characterization studies of Flavobacterium psychrophilum have nonetheless been published (e.g. Holt 1987, Bertolini et al. 1994, Lorenzen et al. 1997, Lorenzen \& Olesen 1997, Crump et al. 2001, Valdebenito \& Avendaño-Herrera 2009), and several of the characteristics have, in many studies, been identical between isolates. However, some differences in biochemical characteristics (Bertolini et al. 1994), cell surface appearance, whole cell proteins (Holt 1987), association with rainbow trout Oncorhynchus mykiss phagocytes (Wiklund \& Dalsgaard 2003), hydrophobicity and hemagglutination (Møller et al. 2003) have been found between F. psychrophilum isolates. Some of these differences have been associated with the virulence of the isolates studied, but some have been unexplainable. Since many of the characteristics indicated above are associated with the structure of the bacterial cell surface, our hypothesis was that some of the differences previously reported between the isolates examined could be associated with the 2 colony phenotypes of $F$. psychrophilum and that phase variation could occur in this pathogen.

The aim of the present study was to characterize smooth and rough colony phenotypes of 4 different Flavobacterium psychrophilum isolates using serological, biochemical, physiological, molecular and virulence tests to examine whether the 2 phenotypes differ from each other and also whether a switch between phenotypes, i.e. phase variation, could occur in this pathogen.

\section{MATERIALS AND METHODS}

Bacterial isolates and growth conditions. The 4 Flavobacterium psychrophilum isolates (P13-4/96, P61/07, P6-3/07 and P6-8/07) used in the present study were all previously isolated in 1996 and 2007 from spleen or kidney of diseased farmed rainbow trout Oncorhynchus mykiss at our laboratory. All isolates contained smooth (S) (Fig. 1A) and rough (R) (Fig. 1B) colony phenotypic variants that were separated for the study and thereafter named after the corresponding colony type as P13-4S/96, P13-4R/96, P6-1S/07, P61R/07, P6-3S/07, P6-3R/07, P6-8S/07 and P6-8R/07. All variants were identified as $F$. psychrophilum by polymerase chain reaction (PCR) (Wiklund et al. 2000). The F. psychrophilum type strain NCIMB $1947^{\mathrm{T}}$ and the wild type (WT) isolate P13-4/96 were also included in the study for comparison. The bacteria were cultured
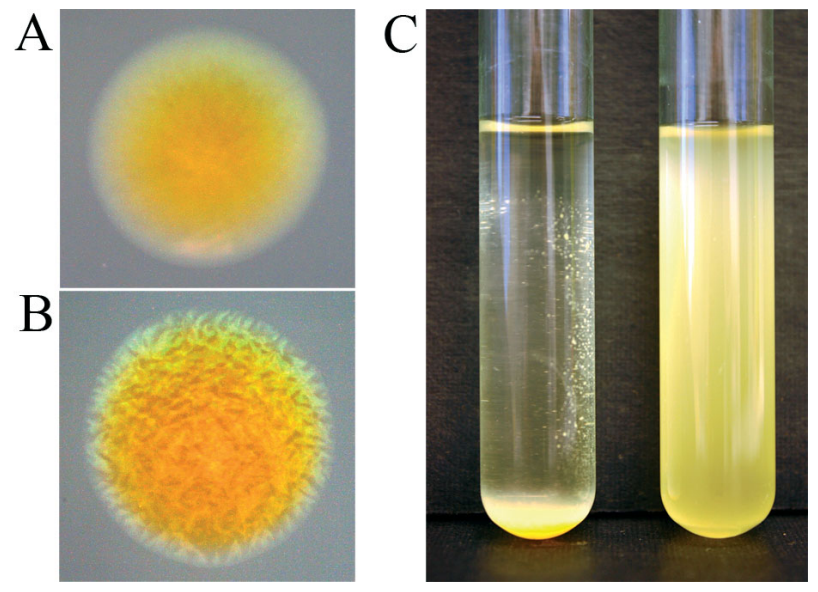

Fig. 1. Flavobacterium psychrophilum. Typical appearance of (A) a smooth and (B) a rough colony type, grown on tryptone yeast extract salts (TYES) agar. (C) In TYES broth the smooth colony type cells autoagglutinated at the bottom of the tube (left), while the rough colony type cells showed a non-agglutinating and uniform growth mode (right)

on tryptone yeast extract salts (TYES) agar and in TYES broth (Holt et al. 1993) at $15^{\circ} \mathrm{C}$. Stock suspensions of all isolates were stored at $-70^{\circ} \mathrm{C}$ in TYES broth supplemented with $20 \%$ glycerol.

Serotyping. The bacterial cells were serotyped 3 times using a slide agglutination test (Madetoja et al. 2001) with minor modifications. Bacterial colonies, grown on TYES agar for $3 \mathrm{~d}$, were suspended in $300 \mu \mathrm{l}$ sodium acetate buffer $(0.1 \mathrm{M} \mathrm{NaCl}, 0.05 \mathrm{M}$ $\mathrm{NaCOOCH}_{3}, \mathrm{pH} 7.5$ ) and heated at $56^{\circ} \mathrm{C}$. Equal volumes of the bacterial suspensions and rabbit antiserum (cross-absorbed anti-Fp ${ }^{\mathrm{T}}$, anti-Fd and anti-Th sera) were mixed on a glass slide, and the agglutination reaction was recorded. Two negative controls, preimmune serum and $0.9 \% \mathrm{NaCl}$, were included in all tests.

Biochemical tests. The bacterial cells were biochemically characterized using tests suitable for Flavobacterium psychrophilum, including hydrolysis of starch (Pacha 1968), casein (Bernardet 1989), gelatin, esculin (Madetoja et al. 2001) and elastin, production of catalase (Madetoja et al. 2002), absorption of Congo red (Ishiguro et al. 1985), presence of flexirubin-type pigments (Lorenzen et al. 1997) and cytochrome oxidase activity using the BBL ${ }^{\mathrm{TM}}$ Oxidase Reagent Droppers (BD). The enzymatic activity of the bacterial cells was also tested using a semi-quantitative micromethod, API ZYM (bioMérieux), in which the strips were incubated for 17 to $19 \mathrm{~h}$ at $15^{\circ} \mathrm{C}$. The gliding motility of the bacterial cells was tested on TYES medium supplemented with $0.5 \%$ agar and $0.1 \%$ baker's yeast. Bacterial cells grown on TYES agar for $3 \mathrm{~d}$ were suspended in TYES broth, and $5 \mu \mathrm{l}$ of the cell suspensions was 
inoculated onto TYES agar-yeast plates. The plates were read after $7 \mathrm{~d}$ of incubation, and any spreading of the bacteria around the inoculation site was noted as gliding motility.

Growth mode in broth. The growth mode of the P134S/96, P13-4R/96, P6-1S/07 and P6-1R/07 variants was examined in TYES broth. Bacteria grown on TYES agar for $6 \mathrm{~d}$ were suspended in TYES broth in glass tubes and incubated with $200 \mathrm{rpm}$ agitation. Subsamples were taken from each bacterial suspension daily for $17 \mathrm{~d}$. The subsamples were diluted in TYES broth and plated onto TYES agar. Following incubation, colony types were identified and counted. The bacteria were transferred into fresh TYES broth twice a week to enable the bacteria to survive. The macroscopic growth of the bacterial cells in the tubes was also examined daily, and any sign of agglutination was recorded.

Cell surface hydrophobicity. The surface hydrophobicity of the bacterial cells was determined in triplicate by the salt aggregation test (SAT) (Lindahl et al. 1981) and by the microbial adhesion to hydrocarbons (MATH) test (Rosenberg et al. 1980). The bacterial cells grown on TYES agar for $3 \mathrm{~d}$ were suspended in $2 \mathrm{mM} \mathrm{NaH}_{2} \mathrm{PO}_{4}, \mathrm{pH} 6.8$ (SAT test) or phosphate urea magnesium sulfate (PUM) buffer (MATH test; $100 \mathrm{mM}$ $\mathrm{K}_{2} \mathrm{HPO}_{4} \times 3 \mathrm{H}_{2} \mathrm{O}, 50 \mathrm{mM} \mathrm{KH} \mathrm{PO}_{4}, 30 \mathrm{mM}$ urea, $1 \mathrm{mM}$ $\mathrm{MgSO}_{4} \times 7 \mathrm{H}_{2} \mathrm{O}, \mathrm{pH} 7.1$ ) to an optical density (OD) of $1.1 \pm 0.05$ at $590 \mathrm{~nm}$ (Møller et al. 2003). The SAT value was determined to the lowest $\left(\mathrm{NH}_{4}\right)_{2} \mathrm{SO}_{4}$ concentration causing aggregation of the cells. Cells with SAT values $<0.1$ were considered highly hydrophobic, between 0.1 and 1.0 hydrophobic and >1.0 hydrophilic (Møller et al. 2003). Buffer without $\left(\mathrm{NH}_{4}\right)_{2} \mathrm{SO}_{4}$ salt was used as a negative control. In the MATH test, the percentage adhesion of the bacterial cells to $n$-hexadecane (Merck KGaA), $n$-octane and $p$-xylene (Sigma-Aldrich) was determined. The cell surface hydrophobicity (\%A), presented as the percentage adhesion to the hydrocarbon, was calculated using the following equation:

$$
\begin{gathered}
\% \mathrm{~A}=\left[\mathrm{OD}_{590}(\text { initial bacterial suspension })-\right. \\
\left.\mathrm{OD}_{590}(\text { aqueous phase })\right] / \mathrm{OD}_{590}(\text { initial bacterial } \\
\text { suspension })
\end{gathered}
$$

Bacterial adhesion to solid surfaces. The ability of the bacterial cells to adhere to a polystyrene surface was tested according to Vesterlund et al. (2005), with some modifications. Bacteria grown on TYES agar for $5 \mathrm{~d}$ were suspended in phosphate-buffered saline (PBS, pH 7.2), to an OD of $0.45 \pm 0.02$ at $520 \mathrm{~nm}$. Bacterial suspensions and PBS as a negative control were added in quadruplicate to wells of an untreated 96well polystyrene microtiter plate (Nunc) and incubated at $15^{\circ} \mathrm{C}$ for $2 \mathrm{~h}$. Following washing with $\mathrm{PBS}$, the adhered cells were fixed at $60^{\circ} \mathrm{C}$ and then stained with $0.1 \%$ crystal violet (Merck) solution. Excess stain was removed by washing, and stain bound to the adhered cells was subsequently released with citrate buffer (20 mM $\mathrm{C}_{6} \mathrm{H}_{8} \mathrm{O}_{7} \times \mathrm{H}_{2} \mathrm{O}, \mathrm{pH}$ 4.3). The adhesion of the cells was quantified by measuring the absorbance values of the wells at $595 \mathrm{~nm}$, and the values were corrected by subtracting the absorbance value of the negative control.

Preparation of whole cell proteins. Whole cell proteins were extracted from $80 \pm 5 \mathrm{mg}$ of bacterial cells (wet weight), grown on TYES agar for $5 \mathrm{~d}$, by suspending in $1 \mathrm{ml}$ PBS and disrupting by sonication (Branson Sonifier 250 Analog; Branson Ultrasonics) 5 times for $10 \mathrm{~s}$ at $10 \%$ amplitude with 2 min cooling periods between each sonication. The lysates were frozen at $-70^{\circ} \mathrm{C}$ until needed for analysis. Thawed lysates were centrifuged $\left(10000 \times g\right.$ for $5 \mathrm{~min}$ at $\left.4^{\circ} \mathrm{C}\right)$, and the protein concentrations of the lysates were determined using a Pierce BCA Protein Assay Kit (Thermo Scientific) according to the manufacturer's instructions, and then adjusted to $1000 \mu \mathrm{g}$ protein $\mathrm{ml}^{-1}$ with PBS. The samples were subsequently suspended in an equal volume of sample buffer (2\% sodium dodecylsulfate [SDS], 10\% glycerol, $60 \mathrm{mM}$ Tris, $\mathrm{pH} 6.8,40 \mathrm{mM}$ dithiothreitol and $0.01 \%$ bromophenol blue), heated at $60^{\circ} \mathrm{C}$ for $15 \mathrm{~min}$ and centrifuged $(17000 \times g$ for $2 \mathrm{~min}$ at room temperature). The supernatants of the samples were used for further analysis with SDS polyacrylamide gel electrophoresis (SDS-PAGE).

Isolation of outer membrane proteins (OMP). OMPs were isolated from whole bacterial cells according to Møller et al. (2005), with minor modifications. Bacterial cells grown on TYES agar plates for $6 \mathrm{~d}$ were harvested in $25 \mathrm{ml}$ TYES broth and washed with $20 \mathrm{mM}$ Tris- $\mathrm{HCl}, \mathrm{pH} 7.2\left(5000 \times g\right.$ for $30 \mathrm{~min}$ at $\left.4^{\circ} \mathrm{C}\right)$. Pellets were re-suspended in $20 \mathrm{ml}$ of $20 \mathrm{mM}$ Tris- $\mathrm{HCl}$ plus 10 mM EDTA ( $\mathrm{pH}$ 7.2), and the cells were disrupted by sonication (B. Braun Labsonic U., B. Braun Biotech International), with $8 \times 60 \mathrm{~s}$ bursts at $50 \mathrm{~W}$ on ice. Undisrupted cells were removed by centrifugation $\left(5000 \times g\right.$ for $30 \mathrm{~min}$ at $\left.4^{\circ} \mathrm{C}\right)$, and the supernatants were further centrifuged $\left(50000 \times \mathrm{g}\right.$ for $60 \mathrm{~min}$ at $\left.4^{\circ} \mathrm{C}\right)$ (Beckman L8-70 ultracentrifuge; Beckman Coulter). Pellets were treated with $30 \mathrm{ml} 0.5 \% \mathrm{~N}$-lauroylsarcosine (Sigma-Aldrich) in $20 \mathrm{mM}$ Tris- $\mathrm{HCl}$ for $20 \mathrm{~min}$ on ice and $100 \mathrm{rpm}$ agitation. The suspensions were centrifuged as previously, and the pellets were treated for a second time with $4 \mathrm{ml} 0.5 \% \mathrm{~N}$-lauroylsarcosine in $20 \mathrm{mM}$ Tris-HCl. After centrifugation as previously, the isolated OMPs were washed twice with $4 \mathrm{ml} 20 \mathrm{mM}$ Tris- $\mathrm{HCl}$, finally re-suspended in $100 \mu 20 \mathrm{mM}$ Tris$\mathrm{HCl}$ and stored at $-20^{\circ} \mathrm{C}$. The protein concentration was determined in thawed samples as described in the previous paragraph, and then adjusted to $200 \mu \mathrm{g}$ 
protein $\mathrm{ml}^{-1}$ with $20 \mathrm{mM}$ Tris- $\mathrm{HCl}$. The samples were subsequently suspended in an equal volume of sample buffer and heated at $100^{\circ} \mathrm{C}$ for $5 \mathrm{~min}$. Samples were used for further analysis with SDS-PAGE.

Isolation of lipopolysaccharides (LPS). LPSs were extracted from whole bacterial cells, grown on TYES agar for 6 d, according to Valverde et al. (1997), with minor modifications. Briefly, $30 \pm 1 \mathrm{mg}$ bacterial cells (wet weight) were suspended in $60 \mu$ EDTA-TEA (100 mM EDTA titrated to $\mathrm{pH} 7.0$ with triethanolamine) and incubated for $15 \mathrm{~min}$. Following centrifugation, the supernatants were treated with $0.2 \mu \mathrm{g} \mathrm{\mu l}^{-1}$ proteinase K (Sigma-Aldrich) for $60 \mathrm{~min}$ at $60^{\circ} \mathrm{C}$. Proteinase K-digested samples were then incubated with $30 \mu \mathrm{l}$ polymyxin B resin (Affi-Prep Polymyxin Support; Bio-Rad Laboratories) for 15 min. After centrifugation, the resin pellets were washed with washing buffer (100 mM KH $\left.{ }_{2} \mathrm{PO}_{4}, 150 \mathrm{mM} \mathrm{NaCl}, \mathrm{pH} 7.0\right)$, suspended in $50 \mu \mathrm{l}$ sample buffer, boiled for $5 \mathrm{~min}$, sonicated (FinnSonic m03; FinnSonic Oy) in a water bath for $15 \mathrm{~min}$ and used for further analysis with SDS-PAGE. LPS $\left(500 \mu \mathrm{g} \mathrm{ml}^{-1}\right.$ in $10 \mathrm{mM}$ Tris, pH 8.0) from Salmonella enterica serovar Typhimurium (Sigma-Aldrich) was suspended in an equal amount of sample buffer, boiled for $5 \mathrm{~min}$ and used as a control.

Preparation of extracellular products (ECP). ECPs produced by the bacterial cells were prepared by the cellophane overlay method according to Sudheesh et al. (2007), with some modifications. The bacterial cells grown on TYES agar were suspended in $0.5 \% \mathrm{NaCl}$ and spread onto sterile cellophane (Sigma-Aldrich)overlaid TYES agar plates. Following incubation for $6 \mathrm{~d}$, the bacterial cells and the produced ECP were suspended in $1 \mathrm{ml} \mathrm{PBS}$ and centrifuged $(15000 \times g$ for $20 \mathrm{~min}$ at $4^{\circ} \mathrm{C}$ ). The supernatants were further filter sterilized with a $0.22 \mu \mathrm{m}$ membrane filter (Millex-GV; Millipore) and stored at $-70^{\circ} \mathrm{C}$. The protein concentration was determined in thawed samples as described in 'Materials and methods: Preparation of whole cell proteins' and adjusted to $500 \mu \mathrm{g}$ protein $\mathrm{ml}^{-1}$ with PBS and used for further analysis with SDS-PAGE.

SDS-PAGE. SDS-PAGE analyses were performed according to Laemmli (1970), with minor modifications. Whole cell lysates ( $5 \mu \mathrm{g}$ protein), OMP ( $2 \mu \mathrm{g}$ protein), LPS (15 $\mu$ l sample, $2.5 \mu \mathrm{g}$ LPS control) and ECP (5 $\mu \mathrm{g}$ protein) were separated in $12 \%$ polyacrylamide resolving gels with $4 \%$ stacking gels. Samples were electrophoresed using a TV100YK mini vertical electrophoresis unit (Sigma-Aldrich). The samples were run through the stacking gel at $100 \mathrm{~V}$, followed by 130 to $150 \mathrm{~V}$ through the resolving gel until the bromophenol dye ran out of the gel. A protein marker $(7$ to $175 \mathrm{kDa}$; New England Biolabs) was used to estimate the size of the separated molecules. Whole cell protein, OMP and ECP gels were all stained with Bio-Safe
Coomassie stain (Bio-Rad Laboratories), according to the manufacturer's instructions. For visualization of the carbohydrate portions of the LPS components, LPS gels were stained with a modified silver staining method (Fomsgaard et al. 1990).

Virulence in rainbow trout. The degree of virulence, expressed as the $50 \%$ lethal dose $\left(\mathrm{LD}_{50}\right)$, was determined for the P13-4S/96, P13-4R/96, P6-1S/07 and P6-1R/07 variants according to the method of Reed \& Müench (1938). Bacteria grown on TYES agar for $3 \mathrm{~d}$ were suspended in $0.5 \% \mathrm{NaCl}$ to an OD of $0.45 \pm 0.02$ at $520 \mathrm{~nm}$. The bacterial concentrations in the suspensions were determined by diluting and plating subsamples onto TYES agar. Rainbow trout (mean weight: $16 \mathrm{~g}$ ) were anesthetized in $0.05 \mathrm{mg} \mathrm{ml}^{-1}$ benzocaine (Oriola Oy), marked by fin-clipping, and injected intramuscularly (i.m.) with $50 \mu \mathrm{l}$ of 10 -fold decreasing dilutions ranging from approximately $10^{7}$ to $10^{3}$ colony-forming units (CFU) $\mathrm{ml}^{-1}$, with 5 rainbow trout injected per dilution. The fish were kept in $0.226 \mathrm{~m}^{3}$ tanks with continuously flowing and aerated well water $\left(12\right.$ to $\left.14^{\circ} \mathrm{C}\right)$. Mortalities were examined for re-isolation of cells of smooth or rough colonies of the different isolates by inoculating tissue samples from spleen and kidney onto TYES agar.

Statistical analysis. All statistics were analyzed using the Statistical Package of the Social Sciences, Version 15.0 (SPSS). The difference in SAT values, \%A values and absorbance values (adhesion ability) was tested between smooth and rough colony types of corresponding isolate with a 1-way ANOVA or MannWhitney $U$-test. Correlation coefficients between SAT values, \%A values and absorbance values were calculated using Pearson or Spearman correlation analyses. Differences were considered significant when $p<0.05$.

\section{RESULTS}

\section{Serological and biochemical characteristics}

The smooth cells of Flavobacterium psychrophilum could not be serotyped with the slide agglutination test as they showed a spontaneous agglutination reaction with all anti-sera and negative controls. The rough cells, on the other hand, showed 3 different reaction patterns (Th, $\mathrm{Th} / \mathrm{Fp}^{\mathrm{T}}$ and $\mathrm{Fp}^{\mathrm{T}} / \mathrm{Th}_{\text {; }}$ for details see Table 3). The WT isolate reacted strongly with the antiTh sera, but a weak reaction was also noted with the anti-Fd and anti- $\mathrm{Fp}^{\mathrm{T}}$ sera and the negative controls, since the isolate also contained smooth cells. The type strain had a fourth reaction pattern and was identified as serotype $\mathrm{Fp}^{\mathrm{T}}$.

Biochemically, both the smooth and the rough phenotype cells, similarly to the type strain and WT isolate, hydrolyzed gelatin, but not starch and esculin. All vari- 
ants were also caseinase positive and expressed gliding motility, except for the P6-3R/07 cells that were identified as caseinase negative and non-motile. The P13 smooth and rough variants and the WT isolate also degraded elastin. Both phenotypic variants, the type strain and the WT isolate produced flexirubin-type pigments, but did not absorb Congo red, and were cytochrome oxidase negative and catalase positive.

The API ZYM test showed the same reaction pattern for all phenotypic variants as for the type strain and WT isolate, except that all rough type variants showed a higher degree of enzymatic activity for acid phosphatase.

\section{Growth mode in broth}

In TYES broth, the smooth variants demonstrated a distinct growth mode, whereby the cells autoagglutinated and precipitated in clusters at the bottom of the tube or adhered to the tube walls. The rough cells, on the other hand, had a uniform growth mode, resulting in a turbid solution (Fig. 1C). In TYES broth, the rough variants did not change their turbid appearance over time, and the colony type was constantly identified as rough when dilutions of the broth were inoculated on TYES agar (data not shown). However, the growth of the smooth variants shifted from a clear broth with precipitated cell clusters to a more turbid solution, and subsamples inoculated on TYES agar showed both smooth and rough type colonies. For the P13-4S/96 variant, the transformation from smooth cells into rough cells when cultivated in TYES broth was a slower process (Fig. 2A) compared to the P6-1S/07 variant (Fig. 2B).

\section{Cell surface hydrophobicity and bacterial adhesion}

The SAT test (Table 1) indicated that the smooth cells were highly hydrophobic (SAT values $<0.1$ ) and that the rough cells were hydrophilic (SAT values $>$ 1.0). All smooth variants differed significantly compared to the corresponding rough variant. The type strain was identified as hydrophobic, and the WT isolate, as hydrophilic.

The MATH test (Table 1) was used because of the autoagglutinating nature of the smooth variants that also aggregated slightly in the negative SAT control. The cells of both phenotypic variants adhered poorly to $n$-hexadecane, and no significant difference was found between the variants. The smooth cells had, on the other hand, a significantly higher ability to adhere to $n$ octane compared to the rough cells. The type strain had a low ability and the WT isolate a high ability to

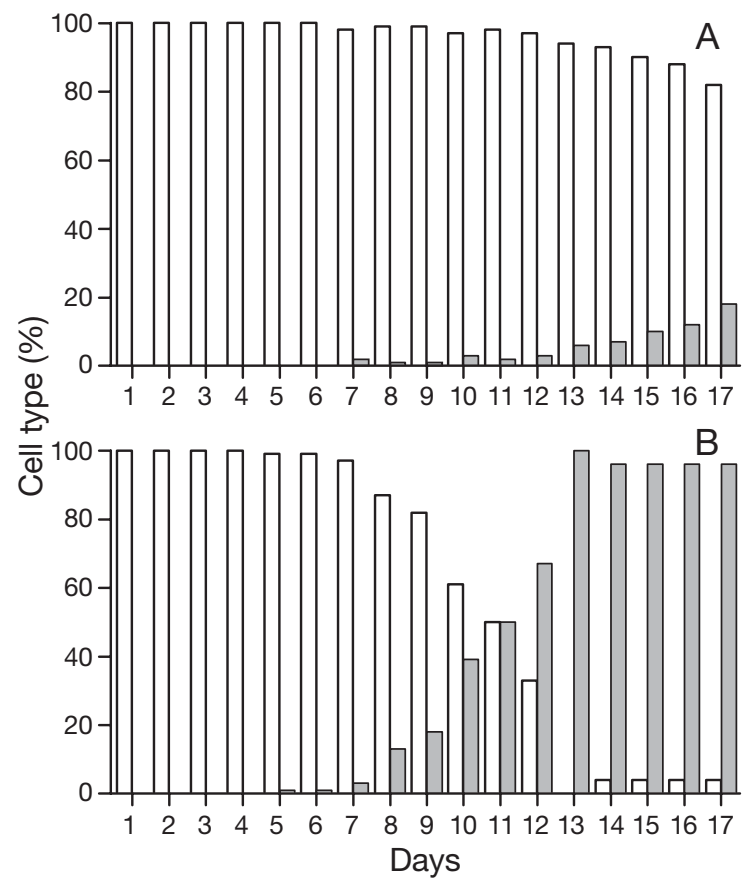

Fig. 2. Flavobacterium psychrophilum. The change of smooth colony type cells into rough type cells for variants (A) P13-4S/96 and (B) P6-1S/07, after repeated passages in broth, observed as a change in turbidity in broth and a subsequent change in colony morphology after plating on TYES agar. White bars: percentage of smooth cell type; grey bars: percentage of rough cell types in relation to incubation time (d)

adhere to $n$-octane. The adhesion to $p$-xylene was not measurable.

The cells of the smooth variants were found to have a significantly higher ability to adhere to polystyrene surfaces compared to the cells of the rough variants (Table 1). The cells of the type strain and the WT isolate adhered poorly to the surface, thus giving low absorbance values similar to the cells of the rough variants.

The SAT values correlated both with the $n$-octane $\%$ A values $\left(\mathrm{r}_{\mathrm{s}}=-0.63, \mathrm{p}<0.001\right)$ and with the $\mathrm{ab}-$ sorbance values from the adhesion test $\left(\mathrm{r}_{\mathrm{s}}=-0.79, \mathrm{p}<\right.$ $0.001)$. The $n$-octane $\% A$ values also correlated with the absorbance values from the adhesion test $\left(\mathrm{r}_{\mathrm{s}}=0.74\right.$, $\mathrm{p}<0.001$ ). Only $n$-octane $\%$ A values correlated moderately with the $n$-hexadecane \%A values $(\mathrm{r}=0.41, \mathrm{p}<$ 0.05).

\section{Characterization of whole cell proteins, cell surface components and ECP}

No distinct differences were found in whole cell protein profiles between cells of smooth and rough colony types. However, the protein profiles of P13-4S/96, P134R/96, P6-3R/07 and the wild type P13-4/96 differed no- 
Table 1. Flavobacterium psychrophilum. Cell surface hydrophobicity and adhesion ability of $F$. psychrophilum variants and isolates used in the present study. For the salt aggregation test (SAT): SAT values $<0.1$ are highly hydrophobic; values fom 0.1 to 1.0 are hydrophobic; values $>1.0$ are hydrophilic. Following the microbial adhesion to hydrocarbons (MATH) test, percentage adhesion to the hydrocarbon (\%A) was used to measure the hydrophobicity of the cells. Adhesion ability was tested by adhesion of the cells to polystyrene surfaces and after staining with crystal violet to measure the absorbance (Abs) at $595 \mathrm{~nm}$. Values are mean \pm SD. Statistically significant difference between smooth (S) and rough (R) types of the corresponding isolate are shown $\left({ }^{*}: \mathrm{p}<0.05 i^{* * *}: \mathrm{p}<0.001\right)$. NM: not measurable

\begin{tabular}{|c|c|c|c|c|c|}
\hline \multirow[t]{2}{*}{ Variant/Isolate } & \multirow[t]{2}{*}{ SAT value } & & \multicolumn{2}{|l|}{$\% \mathrm{~A}$} & \multirow[t]{2}{*}{ Abs $595 \mathrm{~nm}$} \\
\hline & & $n$-hexadecane & $n$-octane & $p$-xylene & \\
\hline P13-4S/96 & $0.03 \pm 0.01^{* * *}$ & $18.8 \pm 3.1$ & $48.3 \pm 1.8^{* * *}$ & NM & $0.055 \pm 0.015^{*}$ \\
\hline $\mathrm{P} 13-4 \mathrm{R} / 96$ & $2.33 \pm 0.12$ & $13.9 \pm 2.6$ & $27.3 \pm 2.7$ & NM & $0.029 \pm 0.002$ \\
\hline $\mathrm{P} 6-1 \mathrm{~S} / 07$ & $0.02 \pm 0.00^{*}$ & $6.3 \pm 0.9$ & $44.5 \pm 2.8^{*}$ & NM & $0.116 \pm 0.014^{* * *}$ \\
\hline $\mathrm{P} 6-1 \mathrm{R} / 07$ & $1.73 \pm 0.12$ & $7.6 \pm 5.8$ & $30.3 \pm 2.4$ & NM & $0.025 \pm 0.003$ \\
\hline $\mathrm{P} 6-3 \mathrm{~S} / 07$ & $0.02 \pm 0.00^{*}$ & $4.4 \pm 3.0$ & $50.5 \pm 1.6^{* * *}$ & NM & $0.081 \pm 0.010^{* * *}$ \\
\hline $\mathrm{P} 6-3 \mathrm{R} / 07$ & $2.33 \pm 0.12$ & $3.6 \pm 2.5$ & $24.2 \pm 1.3$ & NM & $0.006 \pm 0.001$ \\
\hline $\mathrm{P} 6-8 \mathrm{~S} / 07$ & $0.03 \pm 0.01^{* * *}$ & $15.9 \pm 3.1$ & $42.0 \pm 6.2^{*}$ & NM & $0.065 \pm 0.008^{*}$ \\
\hline $\mathrm{P} 6-8 \mathrm{R} / 07$ & $1.08 \pm 0.20$ & $10.7 \pm 7.5$ & $27.5 \pm 2.0$ & NM & $0.027 \pm 0.003$ \\
\hline NCIMB $1947^{\mathrm{T}}$ & $0.53 \pm 0.12$ & $11.9 \pm 7.2$ & $33.1 \pm 1.0$ & NM & $0.034 \pm 0.004$ \\
\hline P13-4/96 (wild type) & $1.87 \pm 0.42$ & $20.4 \pm 1.6$ & $60.5 \pm 7.4$ & NM & $0.026 \pm 0.003$ \\
\hline
\end{tabular}

tably from the other variants examined as well as from the type strain, as they showed more intensely stained bands at approximately 24, 29 and $77 \mathrm{kDa}$ (black arrowheads; Fig. 3). The P13-4S/96 and P6-3R/07 variants also showed a more intensely stained band at approximately $26 \mathrm{kDa}$ compared with the other variants, the type strain and the WT isolate (white arrowheads; Fig. 3). Lower band intensity at approximately 61 and $84 \mathrm{kDa}$ distinguished P13-4S/96 further from all other isolates (white arrows; Fig. 3). Distinct bands at approximately 33, 42, $67,79,127,139$ and $156 \mathrm{kDa}$ also identified the P6-3R/07 variant (black arrows; Fig. 3).
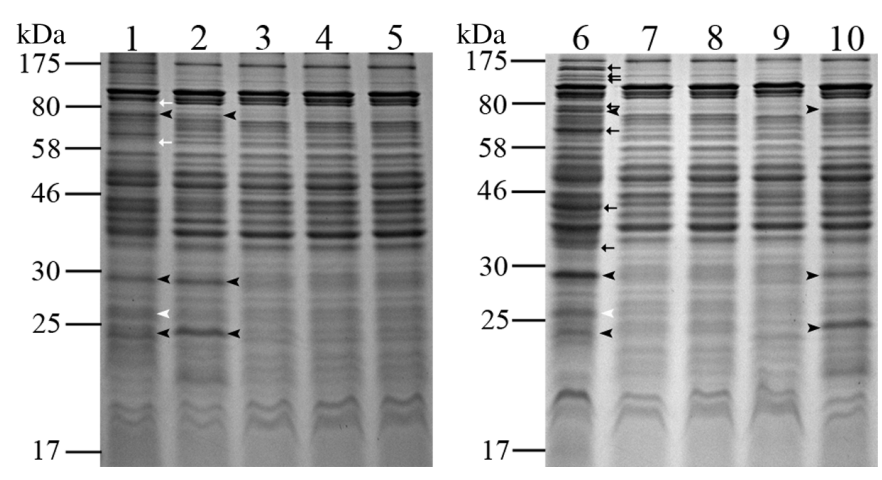

Fig. 3. Flavobacterium psychrophilum. Whole cell protein profiles of smooth (S) and rough (R) variants, the type strain and the wild type isolate used in the present study. Whole cell lysates were separated by sodium dodecyl sulphate polyacrylamide gel electrophoresis (SDS-PAGE) and stained with Bio-Safe Coomassie stain. Lane 1: P13-4S/96; Lane 2: P134R/96; Lane 3: P6-1S/07; Lane 4: P6-1R/07; Lane 5: P6-3S/07; Lane 6: P6-3R/07; Lane 7: P6-8S/07; Lane 8: P6-8R/07; Lane 9: type strain NCIMB $1947^{\mathrm{T}}$; Lane 10: wild type isolate P13-4/96. Black arrowheads: high band intensity at 24, 29 and $77 \mathrm{kDa}$; white arrowheads: high band intensity at $26 \mathrm{kDa}$; black arrows: high band intensity at 33,42, 67, 79, 127, 139 and 156 $\mathrm{kDa}$; white arrows: low band intensity at 61 and $84 \mathrm{kDa}$
The overall banding pattern for the isolated OMPs did not differ between smooth and rough cells or between variants, type strain and WT isolate (Fig. 4). The P6-3R/07 variant, however, showed a few intensely stained bands at approximately 32, 35, 52, 57, 154 and $164 \mathrm{kDa}$, and a band at $>175 \mathrm{kDa}$ was distinct for the type strain NCIMB $1947^{\mathrm{T}}$.

The LPS profiles did not reveal any apparent differences between the smooth and rough cells (Fig. 5). All variants, the type strain and the WT isolate showed 4 distinct bands at approximately 11, 22, 28 and $35 \mathrm{kDa}$ and an indistinct band at approximately $16 \mathrm{kDa}$. Furthermore, the P6 variants and the type strain showed bands at approximately 42, 52 and $58 \mathrm{kDa}$. The type
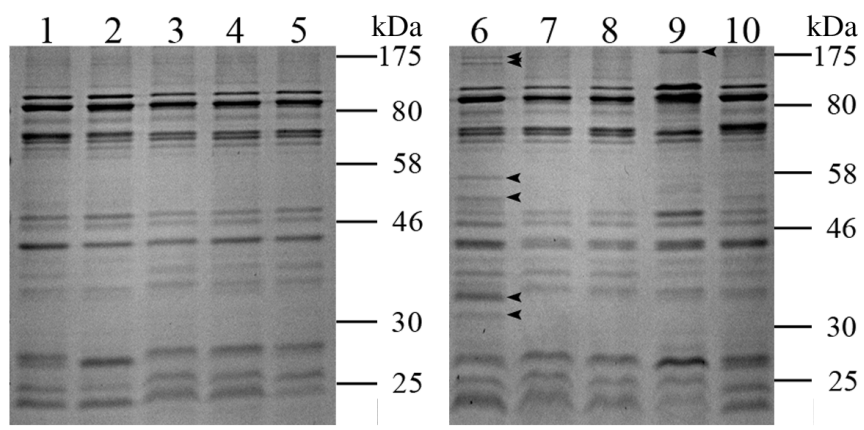

Fig. 4. Flavobacterium psychrophilum. Outer membrane protein (OMP) profiles of smooth (S) and rough (R) variants, the type strain and the wild type isolate used in the present study. Isolated OMPs were suspended in sample buffer, heated at $100^{\circ} \mathrm{C}$, separated by SDS-PAGE and stained with Bio-Safe Coomassie stain. Lane 1: P13-4S/96; Lane 2: P13-4R/96; Lane 3: P6-1S/07; Lane 4: P6-1R/07; Lane 5: P6-3S/07; Lane 6: P63R/07; Lane 7: P6-8S/07; Lane 8: P6-8R/07; Lane 9: type strain NCIMB $1947^{\mathrm{T}}$; Lane 10: wild type isolate P13-4/96. Black arrowheads: distinctly stained bands at $32,35,52,57,154$, 164 and $>174 \mathrm{kDa}$ 

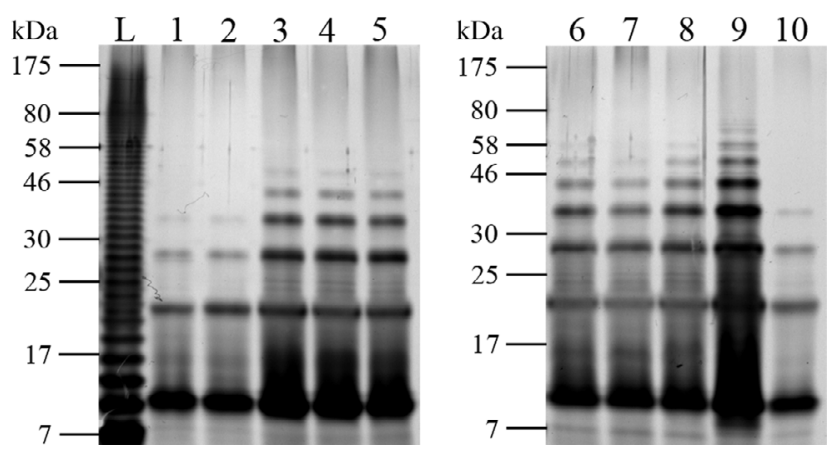

Fig. 5. Flavobacterium psychrophilum. Lipopolysaccharide (LPS) profiles of smooth (S) and rough (R) variants, the type strain and the wild type isolate used in the present study. Isolated LPSs were separated by SDS-PAGE and stained with silver. L: LPS from Salmonella enterica serovar Typhimurium; Lane 1: P13-4S/96; Lane 2: P13-4R/96; Lane 3: P6-1S/07; Lane 4: P6-1R/07; Lane 5: P6-3S/07; Lane 6: P6-3R/07; Lane 7: P68S/07; Lane 8: P6-8R/07; Lane 9: type strain NCIMB $1947^{\mathrm{T}}$; Lane 10: wild type isolate P13-4/96

strain was the only isolate showing a band at approximately $67 \mathrm{kDa}$.

The banding pattern of the ECP samples showed a few variations in the 55 to $95 \mathrm{kDa}$ region between the smooth and rough variants (Fig. 6). The P13-4R/96 variant and the WT isolate showed 5 intensely stained bands at approximately 55, 65, 68, 84 and 94 kDa compared to the P13-4S/96 variant (black arrowheads; Fig. 6). The P6 rough variants, on the other hand, showed lower band intensity at approximately $88 \mathrm{kDa}$ (black arrows; Fig. 6) compared to the P6 smooth variants. This lower band intensity was also notable for the type strain. The ECP profile of the P6-3R/07 variant was slightly different from the ECP profiles of the cor-
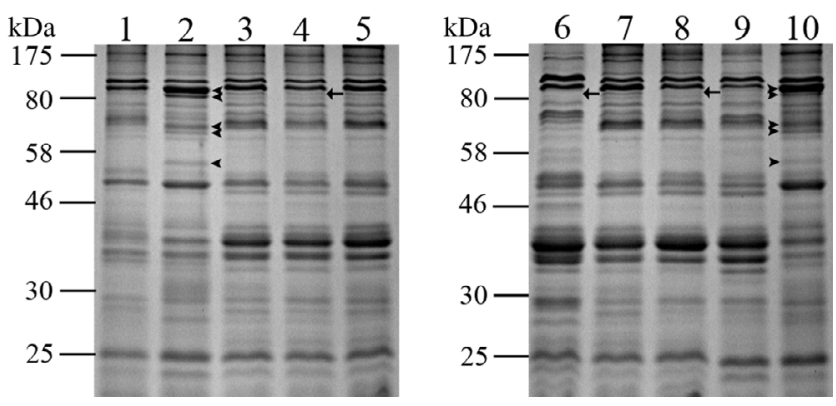

Fig. 6. Flavobacterium psychrophilum. Extracellular product (ECP) profiles of smooth (S) and rough (R) variants, the type strain and the wild type isolate used in the present study. ECPs were separated by SDS-PAGE and stained with BioSafe Coomassie stain. Lane 1: P13-4S/96; Lane 2: P13-4R/96; Lane 3: P6-1S/07; Lane 4: P6-1R/07; Lane 5: P6-3S/07; Lane 6: P6-3R/07; Lane 7: P6-8S/07; Lane 8: P6-8R/07; Lane 9: type strain NCIMB $1947^{\mathrm{T}}$; Lane 10: wild type isolate P13-4/96. Black arrowheads: intensely stained bands at 55, 65, 68, 84 and $94 \mathrm{kDa}$; black arrows: low band intensity at $88 \mathrm{kDa}$ responding smooth variant $\mathrm{P} 6-3 \mathrm{~S} / 07$ and the other P6 variants, showing a similar ECP profile to the type strain in this case.

\section{Virulence in rainbow trout}

All Flavobacterium psychrophilum variants tested were virulent for rainbow trout Oncorhynchus mykiss. The rough cells, however, were slightly more virulent than the smooth cells. The $\mathrm{LD}_{50}$ value was calculated from the percent mortality for the bacterial concentrations of each variant (Table 2), and for P13-4R/96 the $\mathrm{LD}_{50}$ value was $3.58 \times 10^{4} \mathrm{CFU} \mathrm{ml}^{-1}$, whereas for P13$4 \mathrm{~S} / 96$ it was almost 6 -fold higher at $1.98 \times 10^{5} \mathrm{CFU}$ $\mathrm{ml}^{-1}$. The difference in virulence between P6-1R/07 and P6-1S/07 was only 3-fold, with $\mathrm{LD}_{50}$ values of $1.30 \times 10^{4}$ and $3.27 \times 10^{4} \mathrm{CFU} \mathrm{ml}^{-1}$, respectively.

The smooth and rough cells did not switch phenotype in the infected fish, i.e. the same colony type cells that had been injected were always re-isolated from the spleen and kidney of the dead or moribund rainbow trout.

\section{DISCUSSION}

A large number of characterization studies on Flavobacterium psychrophilum have been done previously (see Nematollahi et al. 2003); however, occurrence of phase variation in $F$. psychrophilum or the possibility that different colony phenotypes can have diverse characteristics have not been considered. In the present study, smooth and rough colony phenotype cells of $4 \mathrm{~F}$. psychrophilum isolates were therefore characterized in an attempt to gain a better understanding of the pathogenesis of this fish pathogen.

In the serotyping test, there was a notable difference between the smooth and rough phenotypes, since the smooth cells could not be serotyped due to their autoagglutinating trait. All rough cells, on the other hand, could be serotyped, and all reacted with the anti-Th serum, which indicates that the rough phenotype cells share antigens. However, P13-4R/96 was the only variant that reacted solely with the anti-Th serum, while P6-1R/07 and P6-8R/07 also reacted weakly with the anti-Fp ${ }^{\mathrm{T}}$ serum. The P6-3R/07 variant, on the other hand, reacted strongly with the anti- $\mathrm{Fp}^{\mathrm{T}}$ serum and weakly with the anti-Th serum. Therefore, according to the serotyping system by Lorenzen \& Olesen (1997), the P6-1R/07 and P6-8R/07 variants belong to serotype Th, subtype Th-1, and the P6-3R/07 variant to serotype Th, but subtype Th-2. The reaction with the anti-Fp ${ }^{T}$ serum also indicates that the P6 rough cells share antigens with the type strain. From these results, however, 
Table 2. Flavobacterium psychrophilum. Percent mortality of rainbow trout Oncorhynchus mykiss injected intramuscularly with serially diluted bacterial suspensions (colony-forming units [CFU] $\mathrm{ml}^{-1}$ ) of variants P13-4S/96, P13-4R/96, P6-1S/07 and P6-1R/07. Five rainbow trout per bacterial concentration were injected, and the percent mortality was calculated based on the total dead and living rainbow trout for each variant (Reed \& Müench 1938)

\begin{tabular}{|lcccc|}
\hline \multirow{2}{*}{$\left.\begin{array}{l}\text { Bacterial } \\
\text { Concentration } \\
(\text { CFU ml }\end{array}{ }^{-1}\right)$} & P13-4S/96 & P13-4R/96 & P6-1S/07 & P6-1R/07 \\
\cline { 2 - 5 } & & & & \\
\hline $10^{7}$ & 100 & 100 & 100 & 100 \\
$10^{6}$ & 88 & 100 & 85 & 100 \\
$10^{5}$ & 50 & 78 & 73 & 88 \\
$10^{4}$ & 0 & 44 & 40 & 43 \\
$10^{3}$ & 0 & 20 & 18 & 11 \\
\hline
\end{tabular}

it is not possible to determine whether the smooth and rough phenotype cells have different or the same antigenic properties, since the smooth cells could not be serotyped.

Biochemically, there were no differences between the smooth and rough cells of the corresponding isolates, and, overall, the biochemical profiles for all variants were the same as that of the type strain and in accordance with previous studies (Pacha 1968, Bernardet \& Kerouault 1989, Madetoja et al. 2001). The only difference was found between the smooth and rough variants of the P6-3/07 isolate, as the rough variant was caseinase negative and non-motile. To our knowledge this is the first time that a caseinase negative Flavobacterium psychrophilum variant has been reported, although strong proteolytic activity against casein has previously been considered a significant characteristic for F. psychrophilum (Bernardet \& Kerouault 1989). In Aeromonas salmonicida, however, the inability to degrade casein has been associated with the loss of hemolytic activity (Titball et al. 1985), which is also a possible virulence factor in F. psychrophilum (Lorenzen et al. 1997). A non-motile mutant of F. psychrophilum has, however, previously been described; this was found to attenuate virulence for rainbow trout Oncorhynchus mykiss, but to possess an enhanced ability to form biofilms (Álvarez et al. 2006). The inability to hydrolyze casein and express gliding motility does not, however, seem to be a typical characteristic for the rough phenotype as this was found for only 1 of the rough variants. Thus, these results indicate that the genes encoding for metabolism-associated proteins do not seem to be expressed differently in the 2 phenotypic variants.

A difference between the smooth and rough cells was found using the API ZYM method. The test showed that the cells of all rough variants expressed a higher degree of acid phosphatase activity. Acid phosphatases are soluble, bacterial-secreted phospho- hydrolases or membrane-bound lipoproteins that can hydrolyze a broad variety of structurally different substrates (Roszak \& Colwell 1987), and they have been found to be important virulence factors for other Gram-negative bacterial pathogens in that they enable the bacteria to survive in host phagocytes (Baca et al. 1993, Mohapatra et al. 2008). Whether the higher acid phosphatase activity plays a significant role in the enhanced virulence of the rough phenotype compared to the smooth one, needs, however, to be investigated further. Flavobacterium psychrophilum cells of unknown colony phenotype have been reported to be able to survive and multiply in spleen phagocytes of rainbow trout fry (Decostere et al. 2001).

When grown in TYES broth, the smooth and rough cells had distinctly different physiological characteristics, as the smooth cells autoagglutinated at the bottom of the tube, while the rough cells grew uniformly in the broth. The autoagglutinating ability of other Gramnegative bacteria has been associated with virulence (Sakai 1986, Menozzi et al. 1994) and with different surface structures on the bacterial cells, such as outer membrane proteins in Yersinia species (Skurnik et al. 1984), filamentous hemagglutinin in Bordetella pertussis (Menozzi et al. 1994) and the electrical charge of the cell surface in Aeromonas salmonicida (Sakai 1986). However, the autoagglutinating trait of the smooth Flavobacterium psychrophilum variants in the present study does not seem to be directly associated with virulence, since both phenotypic variants were virulent for rainbow trout. In phase-varying bacteria, autoagglutination is often observable when the phase variation involves changes in surface structures (Henderson et al. 1999).

The ability of bacteria to convert from one colony type cell into another in liquid media has previously been described for several bacterial species (Braun 1947, Hilton et al. 2006). In the present study, the smooth cells could convert into rough ones, but not vice versa when grown in TYES broth. Furthermore, no change in colony morphology was noted for either colony type when grown on solid TYES agar. These observations indicate that phase variation occurs in Flavobacterium psychrophilum and that it is sensitive to growth conditions. Furthermore, the conditions in the TYES broth appear to select the rough, non-agglutinating phenotype, suggesting that the phase variation involves one or several surface structures. Phase variation from opaque to translucent colony phenotype has also been found in Vibrio vulnificus cultured in 
broth, and this variation was suggested to be irreversible (Hilton et al. 2006). It is also possible that the phase variation from smooth to rough cells of F. psychrophilum is irreversible or that the growth conditions for the conversion from rough into smooth cells are still to be found. This avenue, however, needs to be further investigated if a switch between phenotypes can occur in vivo. From the virulence test, however, it was observed that there was no switch between phenotypes when the smooth or rough cells were injected into the fish.

A crucial step in bacterial pathogenesis is the ability to attach to and colonize host surfaces, and, for aquatic pathogens, high surface hydrophobicity may be significant in their adherence ability (reviewed in Bar-Or 1990). In the present study, it was found that the smooth cells were both highly hydrophobic and had a higher ability to adhere to polystyrene surfaces compared to the hydrophilic rough cells. Variation in hydrophobicity SAT-values has previously been found for different isolates of Flavobacterium psychrophilum, but the variation in hydrophobicity could not be correlated with the serotype or virulence of the isolates (Møller et al. 2003). Vatsos et al. (2001) also found that the ability of different $F$. psychrophilum isolates to adhere to $n$ hexadecane and rainbow trout eggs was correlated. The colony type of the cells of the isolates tested in these 2 studies was not reported; however, the presence of different colony types could be the reason for the differences found in hydrophobicity and adherence ability. Since cells of both smooth and rough colony types of F. psychrophilum were found to be virulent for rainbow trout, hydrophobicity and adherence ability do not seem to be directly associated with the virulence capacity of the 2 phenotypes. However, the virulence of the isolates studied by Møller et al. (2003) was, similar to procedures in the present study, examined by an injection challenge, as successful immersion challenges with F. psychrophilum are difficult to achieve. The attachment of bacterial cells to host surfaces was therefore completely disregarded, so that a direct association between virulence and adhesion ability cannot be made in this case. The finding that both phenotypes can induce mortality when injected into the fish is supported by the fact that both phenotypes can be isolated from diseased, farmed rainbow trout (authors' unpubl. results). The hydrophobic cell surface and the high adherence ability of the smooth phenotype may also have important consequences for the attachment of cells to the host and to environmental surfaces, but this hypothesis needs to be examined further.

The hydrophobicity and adhesiveness of a bacterial cell is associated with the chemical and physiological structures of the cell surface (Bar-Or 1990). Phase variation in bacteria is also linked to surface components, since changes in these components often affect colony morphology by, for example, altering the packing of the cells on agar surfaces (van der Woude \& Bäumler 2004). No distinct differences in whole cell protein or OMP profiles between the smooth and rough cells were noted, however. The only differences found in whole cell protein profiles were between the P13 and P6 isolates, which could in part be due to the different ages of the isolates. The whole cell protein and OMP banding pattern of the caseinase negative and non-motile rough variant P6-3R/07 was also clearly different from the banding patterns of the other isolates, but further investigations are needed to explain these differences. The OMP banding patterns of the isolates in the present study were quite similar overall to the OMP banding patterns of Danish and Chilean Flavobacterium psychrophilum isolates (Møller et al. 2005, Valdebenito \& Avendaño-Herrera 2009). The LPS profiles did not reveal any differences between the smooth and rough cells either; only variability between isolates was found. Variations occurred in the number of O-polysaccharide chain repeating units, with the $\mathrm{P} 13$ isolates having only 5 , the P6 isolates 8 and the type strain 9 repeating units. The variability in the number of O-polysaccharide chain repeating units could be linked to the difference in the serotypes of the rough variants, as these structures have been used for serotyping F. psychrophilum (Wakabayashi et al. 1994). The LPSs of both the smooth and rough cells of $F$. psychrophilum were found to be smooth, which is in accordance with previous studies (LaFrentz et al. 2007, Valdebenito \& Avendaño-Herrera 2009). Since no distinct differences in total protein, OMP and LPS banding patterns were found between the smooth and rough cells, the possible differences in surface structures are probably located somewhere else, e.g. in the polysaccharide capsule or glycocalyx surrounding the F. psychrophilum cells (Crump et al. 2001, LaFrentz et al. 2007). Capsular polysaccharides are known to be associated with phase variation (van der Woude \& Bäumler 2004), adhesion ability (Hsieh et al. 2003), autoagglutination and also cell surface hydrophilicity (Bonet et al. 1993) in Gram-negative bacteria. A detailed characterization of the glycocalyx of the 2 colony phenotypes of F. psychrophilum is planned for future research.

Extracellular proteases have been suggested to play a significant role in the pathogenesis of Flavobacterium psychrophilum (Bertolini et al. 1994, reviewed by Nematollahi et al. 2003); it has also been found that different phenotypic variants in phase-varying bacteria, e.g. Pseudomonas brassicacearum, may express extracellular products differently (Chabeaud et al. 2001). In the present study, a difference in ECP profiles between the smooth and rough cells was observed, as the P13 rough variant and the wild type isolate showed 5 intensely 
Table 3. Flavobacterium psychrophilum. Summary of differences in characteristics between smooth (S) and rough (R) phenotypic variants used in the present study. Th: reaction only with anti-Th serum; Th/Fp ${ }^{\mathrm{T}}$ : strong reaction with anti-Th serum and weak reaction with anti-Fp ${ }^{\mathrm{T}}$ serum; $\mathrm{Fp}^{\mathrm{T}} / \mathrm{Th}$ : strong reaction with anti-Fp ${ }^{\mathrm{T}}$ serum and weak reaction with anti-Th serum; TYES: tryptone yeast extract salts; NI: not identifiable; ND: not determined

\begin{tabular}{|c|c|c|c|c|c|c|}
\hline Variant & Serotype & $\begin{array}{l}\text { Acid phosphatase } \\
\text { activity }\end{array}$ & $\begin{array}{l}\text { Autoagglu- } \\
\text { tination }\end{array}$ & $\begin{array}{l}\text { Phenotypic } \\
\text { conversion in } \\
\text { TYES broth }\end{array}$ & $\begin{array}{c}\text { Cell } \\
\text { hydrophobicity }\end{array}$ & $\begin{array}{l}\text { Adhesion } \\
\text { ability }\end{array}$ \\
\hline P13-4S/96 & NI & Low & Yes & Yes & High & High \\
\hline P13-4R/96 & Th & High & No & No & Low & Low \\
\hline P6-1S/07 & NI & Low & Yes & Yes & High & High \\
\hline P6-1R/07 & $\mathrm{Th} / \mathrm{Fp}^{\mathrm{T}}$ & High & No & No & Low & Low \\
\hline P6-3S/07 & NI & Low & Yes & ND & High & High \\
\hline P6-3R/07 & $\mathrm{Fp}^{\mathrm{T}} / \mathrm{Th}$ & High & No & ND & Low & Low \\
\hline P6-8S/07 & NI & Low & Yes & ND & High & High \\
\hline $\mathrm{P} 6-8 \mathrm{R} / 07$ & $\mathrm{Th} / \mathrm{Fp}^{\mathrm{T}}$ & High & No & ND & Low & Low \\
\hline
\end{tabular}

stained bands compared to no bands or weakly stained bands in the P13 smooth variant. Two of these protein bands had approximate molecular weights of 55 and $65 \mathrm{kDa}$ and may be the $55 \mathrm{kDa}$ Fpp1 and the $62 \mathrm{kDa}$ Fpp2 metalloproteases previously found in F. psychrophilum (Secades et al. 2001, 2003), indicating that the P13 rough cells could have a higher ability to hydrolyze a range of matrix and muscle proteins compared to the P13 smooth cells. The 55 and $65 \mathrm{kDa}$ protein bands were not evident, however, in the ECP profiles of the P6 isolates, which could in part be due to the age differences between the isolates. Instead, the P6 smooth cells showed an intensely stained band at approximately 88 $\mathrm{kDa}$ which was not shown for the P6 rough cells. The proteolytic activity of this $88 \mathrm{kDa}$ protein band and the importance of the differences in extracellular proteins between the 2 phenotypes of $F$. psychrophilum have yet to be investigated.

The results of the present study show that phase variation occurs in the fish pathogen Flavobacterium psychrophilum and that the growth conditions tested in the study were selective for the rough phenotype. The smooth and rough phenotypic variants were metabolically similar, but showed distinct physiological characteristics and, to some extent, different enzymatic activities (summarized in Table 3). The autoagglutinating, hydrophobic and adhesive characteristics of the smooth phenotype indicate that one or several surface structures, other than OMPs and LPSs, are most probably involved in the switch between the smooth and the rough phenotypes. Both phenotypic variants were virulent for rainbow trout when injected, but before the importance of the 2 phenotypes for pathogenesis of the bacterium can be clarified, a more natural infection route needs to be tested. In future studies, the biological significance associated with the 2 colony phenotypes and the phase variation in $F$. psychrophilum will be investigated.
Acknowledgements. This study was funded by a grant (No. 123083) from the Academy of Finland. We thank M. L. Hoffrén for assistance with cross-absorbing rabbit antiserum for the slide agglutination test and everyday laboratory support. C. Wikström is thanked for assistance with sample collections when bacteria were grown in liquid media, and T. Johansson, C. Engblom and C. Oetken-Lindholm, for advice concerning molecular techniques. Finally, we thank E. Bonsdorff for critical reading of the manuscript.

\section{LITERATURE CITED}

Álvarez B, Secades P, Prieto M, McBride MJ, Guijarro JA (2006) A mutation in Flavobacterium psychrophilum tlpB inhibits gliding motility and induces biofilm formation. Appl Environ Microbiol 72:4044-4053

Baca OG, Roman MJ, Glew RH, Christner RF, Buhler JE, Aragon AS (1993) Acid phosphatase activity in Coxiella burnetii: a possible virulence factor. Infect Immun 61: 4232-4239

Bar-Or Y (1990) Hydrophobicity in the aquatic environment. In: Doyle RJ, Rosenberg M (eds) Microbial cell surface hydrophobicity. American Society for Microbiology, Washington, DC, p 211-228

Bernardet JF (1989) 'Flexibacter columnaris': first description in France and comparison with bacterial strains from other origins. Dis Aquat Org 6:37-44

Bernardet JF, Kerouault B (1989) Phenotypic and genomic studies of 'Cytophaga psychrophila' isolated from diseased rainbow trout (Oncorhynchus mykiss) in France. Appl Environ Microbiol 55:1796-1800

Bertolini JM, Wakabayashi H, Watral VG, Whipple MJ, Rohovec JS (1994) Electrophoretic detection of proteases from selected strains of Flexibacter psychrophilus and assessment of their variability. J Aquat Anim Health 6: 224-233

Bonet R, Simon-Pujol D, Congregado F (1993) Effects of nutrients on exopolysaccharide and surface properties of Aeromonas salmonicida. Appl Environ Microbiol 59: $2437-2441$

Braun W (1947) Bacterial dissociation. Microbiol Mol Biol Rev 11:75-114

Chabeaud P, de Groot A, Bitter W, Tommassen J, Heulin T, Achouak W (2001) Phase-variable expression of an operon encoding extracellular alkaline protease, a serine protease homolog, and lipase in Pseudomonas brassicacearum. J Bacteriol 183:2117-2120 
Crump EM, Perry MP, Clouthier SC, Kay WW (2001) Antigenic characterization of the fish pathogen Flavobacterium psychrophilum. Appl Environ Microbiol 67: 750-759

> Decostere A, D'Haese E, Lammens M, Nelis H, Haesebrouck F (2001) In vivo study of phagocytocis, intracellular survival and multiplication of Flavobacterium psychrophilum in rainbow trout, Oncorhynchus mykiss (Walbaum), spleen phagocytes. J Fish Dis 24:481-487

Fomsgaard A, Freudenberg MA, Galanos C (1990) Modification of the silver staining technique to detect lipopolysaccharide in polyacrylamide gels. J Clin Microbiol 28: 2627-2631

> Henderson IR, Owen P, Nataro JP (1999) Molecular switches - the on and off of bacterial phase variation. Mol Microbiol 33:919-932

Hilton T, Rosche T, Froelich B, Smith B, Oliver J (2006) Capsular polysaccharide phase variation in Vibrio vulnificus. Appl Environ Microbiol 72:6986-6993

Holt RA (1987) Cytophaga psychrophila, the causative agent of bacterial cold-water disease in salmonid fish. $\mathrm{PhD}$ dissertation, Oregon State University, Corvallis

Holt RA, Rohovec JS, Fryer JL (1993) Bacterial cold-water disease. In: Inglis V, Roberts RJ, Bromage NR (eds) Bacterial diseases of fish. Blackwell Scientific Publications, Oxford, p 3-23

Hsieh YC, Liang SM, Tsai WL, Chen YH, Liu TY, Liang CM (2003) Study of capsular polysaccharide from Vibrio parahaemolyticus. Infect Immun 71:3329-3336

Ishiguro EE, Ainsworth T, Trust TJ, Kay WW (1985) Congo red agar, a differential medium for Aeromonas salmonicida, detects the presence of the cell surface protein array involved in virulence. J Bacteriol 164:1233-1237

Laemmli UK (1970) Cleavage of structural proteins during the assembly of the head of bacteriophage T4. Nature 227: $680-685$

LaFrentz BR, Lindstrom NM, LaPatra SE, Call DR, Cain KD (2007) Electrophoretic and western blot analyses of the lipopolysaccharide and glycocalyx of Flavobacterium psychrophilum. Fish Shellfish Immunol 23:770-780

Lindahl M, Faris A, Wadström T, Hjertén S (1981) A new test based on 'salting out' to measure relative surface hydrophobicity of bacterial cells. Biochim Biophys Acta 677: 471-476

Lorenzen E, Olesen NJ (1997) Characterization of isolates of Flavobacterium psychrophilum associated with coldwater disease or rainbow trout fry syndrome II: serological studies. Dis Aquat Org 31:209-220

> Lorenzen E, Dalsgaard I, Bernardet JF (1997) Characterization of isolates of Flavobacterium psychrophilum associated with coldwater disease or rainbow trout fry syndrome I: phenotypic and genomic studies. Dis Aquat Org 31:197-208

Madetoja J, Hänninen ML, Hirvelä-Koski V, Dalsgaard I, Wiklund T (2001) Phenotypic and genotypic characterization of Flavobacterium psychrophilum from Finnish fish farms. J Fish Dis 24:469-479

Madetoja J, Dalsgaard I, Wiklund T (2002) Occurrence of Flavobacterium psychrophilum in fish-farming environments. Dis Aquat Org 52:109-118

> Menozzi FD, Boucher PE, Riveau G, Gantiez C, Locht C (1994) Surface-associated filamentous hemagglutinin induces autoagglutination of Bordetella pertussis. Infect Immun 62:4261-4269

Mohapatra NP, Soni S, Reilly TJ, Liu J, Klose KE, Gunn JS (2008) Combined deletion of four Francisella novicida acid phosphatases attenuates virulence and macrophage vacuolar escape. Infect Immun 76:3690-3699

Møller JD, Larsen JL, Madsen L, Dalsgaard I (2003) Involvement of a sialic acid-binding lectin with hemagglutination and hydrophobicity of Flavobacterium psychrophilum. Appl Environ Microbiol 69:5275-5280
Møller JD, Barnes AC, Dalsgaard I, Ellis AE (2005) Characterisation of surface blebbing and membrane vesicles produced by Flavobacterium psychrophilum. Dis Aquat Org 64:201-209

> Nematollahi A, Decostere A, Pasmans F, Haesebrouck F (2003) Flavobacterium psychrophilum infections in salmonid fish. J Fish Dis 26:563-574

> Pacha RE (1968) Characteristics of Cytophaga psychrophila (Borg) isolated during outbreaks of bacterial cold-water disease. Appl Microbiol 16:97-101

Reed LJ, Müench H (1938) A simple method of estimating fifty per cent endpoints. Am J Hyg 27:493-497

Rosenberg M, Gutnick D, Rosenberg E (1980) Adherence of bacteria to hydrocarbons: a simple method for measuring cell-surface hydrophobicity. FEMS Microbiol Lett 9:29-33

Roszak DB, Colwell RR (1987) Survival strategies of bacteria in the natural environment. Microbiol Rev 51:365-379

Sakai DK (1986) Electrostatic mechanism of survival of virulent Aeromonas salmonicida strains in river water. Appl Environ Microbiol 51:1343-1349

> Secades P, Alvarez B, Guijarro JA (2001) Purification and characterization of a psychrophilic, calcium-induced, growth-phase-dependent metalloprotease from the fish pathogen Flavobacterium psychrophilum. Appl Environ Microbiol 67:2436-2444

> Secades P, Alvarez B, Guijarro JA (2003) Purification and properties of a new psychrophilic metalloprotease (Fpp2) in the fish pathogen Flavobacterium psychrophilum. FEMS Microbiol Lett 226:273-279

> Skurnik M, Bölin I, Heikkinen H, Piha S, Wolf-Watz H (1984) Virulence plasmid-associated autoagglutination in Yersinia spp. J Bacteriol 158:1033-1036

> Sudheesh PS, LaFrentz BR, Call DR, Siems WF, LaPatra SE, Wiens GD, Cain KD (2007) Identification of potential vaccine target antigens by immunoproteomic analysis of a virulent and a non-virulent strain of the fish pathogen Flavobacterium psychrophilum. Dis Aquat Org 74:37-47

Titball RW, Bell A, Munn CB (1985) Role of caseinase from Aeromonas salmonicida in activation of hemolysin. Infect Immun 49:756-759

Valdebenito S, Avendaño-Herrera R (2009) Phenotypic, serological and genetic characterization of Flavobacterium psychrophilum strains isolated from salmonids in Chile. J Fish Dis 32:321-333

Valverde C, Hozbor DF, Lagares A (1997) Rapid preparation of affinity-purified lipopolysaccharide samples for electrophoretic analysis. Biotechniques 22:230-232

van der Woude MW (2006) Re-examining the role and random nature of phase variation. FEMS Microbiol Lett 254: 190-197

> van der Woude MW, Bäumler AJ (2004) Phase and antigenic variation in bacteria. Clin Microbiol Rev 17:581-611

- Vatsos IN, Thompson KD, Adams A (2001) Adhesion of the fish pathogen Flavobacterium psychrophilum to unfertilized eggs of rainbow trout (Oncorhynchus mykiss) and nhexadecane. Lett Appl Microbiol 33:178-182

Vesterlund S, Paltta J, Karp M, Ouwehand AC (2005) Measurement of bacterial adhesion - in vitro evaluation of different methods. J Microbiol Methods 60:225-233

Wakabayashi H, Toyama T, Iida T (1994) A study on serotyping of Cytophaga psychrophila isolated from fishes in Japan. Fish Pathol 29:101-104

Wiklund T, Dalsgaard I (2003) Association of Flavobacterium psychrophilum with rainbow trout (Oncorhynchus mykiss) kidney phagocytes in vitro. Fish Shellfish Immunol 15: 387-395

Wiklund T, Madsen L, Bruun MS, Dalsgaard I (2000) Detection of Flavobacterium psychrophilum from fish tissue and water samples by PCR amplification. J Appl Microbiol 88: 299-307 